\title{
The Toronto Meeting of the British Association.
}

Provisional Programmes of Sections.

PROVISIONAL programmes of the Sections of the British Association for the Toronto meeting on August 6-I3 have now been arranged, from which it appears that those who attend the meeting will be very fully occupied. The meeting will be noteworthy for the number of American and Canadian men of science who are presenting papers and taking part in many of the joint discussions.

We are indebted to the Recorders of the Sections for the following brief statements of important features of the work of the various Sections.

Section A (Mathematics and Physics).

The outstanding feature of an extensive programme is the discussion which has been arranged, jointly with Section B, on crystal structure. The presidential address which Sir William Bragg will deliver on "The Analysis of Crystal Structure by X-rays" will form the introduction to this discussion, to which, among others, Prof. W. L. Bragg, Prof. S. Chapman, Dr. Shearer, Prof. Desch, and, possibly, Prof. Siegbahn (of Upsala) will contribute.

The exceptional equipment of the Toronto physical laboratory lends special interest to the paper promised by Prof. McLennan on " Recent Developments in Low Temperature Research," because the liquefaction of helium and the luminescence of solid nitrogen will be demonstrated. The United States, as well as Britain and Canada, will be well represented in the programme; the papers by Drs. Mohler and Foote on "Critical Potentials and their Interpretation," Prof. A. H. Compton on "The Quantum Theory of the Scattering of X-rays," Prof. Duane on " Secondary and Tertiary Radiation," and one by Prof. R. W. Wood may be mentioned.

Among the visitors to Canada, Prof. A. Fowler will read a paper on "The Spectra of Ionised Elements," Mr. R. H. Fowler will deal with "Mechanisms of Excitation, Ionisation, and Dissociation in Statistical Theory," and Prof. C. V. Raman will take a principal part in a discussion of the scattering of light.

There are many meteorological and geophysical papers promised, and the Section will have to subdivide in order to deal with them. Sir Napier Shaw has chosen the subject "If the Earth went Dry," and Mr. F. J. W. Whipple and Mr. L. F. Richardson, who are alșo going from England, will read papers. Canada itself is providing a number of meteorological papers; Sir Frederic Stupart, the Director of the Canadian Meteorological Office, has given as his subject " The Variableness of Canadian Winters." Astronomy will occupy a whole morning; papers are expected from Prof. Eddington on "Theory of Outflow of Radiation from a Star," Dr. H. H. Plaskett on "The Spectra of Nebulæ," and Dr. Silberstein on " Determination of the Curvature Radius of Spacetime."

A special feature is being made of afternoon sectional lectures, of which there will be no less than three, and those of exceptional interest. Sir Ernest Rutherford will lecture on "Atomic Disintegration," Sir Richard Paget on "The Nature of Speech," and Prof. V. Bjerknes (of Bergen) on "The Forces which lift Aeroplanes." The last two will be illustrated by experiments. It is hoped to arrange short sessions of the Section at Saskatoon and Edmonton during the transcontinental excursion following the Toronto meeting. Sir Richard Paget has promised to lecture at both places.

\section{Section B (Chemistry).}

Chemistry will be represented by a good attendance from Great Britain, and interesting meetings are expected. The president, Sir Robert Robertson, has selected "Chemistry and the State" as the subject of his address, and he will also deliver a lecture on explosives. The Section will join with Section A (Mathematics and Physics) in a discussion on crystal structure, and with Section I (Physiology) in one on vitamins, particulars of which will be found under the programmes of those sections. A morning will be devoted to a discussion on electrochemical industries, with special reference to Canada, Mr. H. Freeman dealing with Canadian hydro-electric development, Mr. D. A. Pritchard with the Canadian Salt Co.'s processes, Mr. R. L. Peek with electrolytic nickel, Mr. F. A. J. Fitzgerald with a radiant resistor furnace, and other contributors being Mr. F. A. Lidbury and Prof. F. G. Donnan.

Section C (Geology) will join in a discussion on liquid and powdered fuels, Dr. G. S. Hume reviewing the liquid fuels of Canada, Prof. G. A. Guess describing the use of powdered fuel in metallurgical plants, and Prof. W. A. Bone that of Canadian lignites. In another session, Prof. Bone will deal with the activation of nitrogen in explosions. An important discussion, in which Section A will join, is that on colloids, which will be opened by Prof. J. W. McBain with a group of papers dealing mainly with soaps, whilst Prof. W. D. Bancroft will speak on the permeability of membranes, Prof. E. F. Burton on the mutual action of electrically charged particles in solution, Prof. W. Lash Miller on the distribution of colloidal gold between two liquid phases, Prof: F. B. Kenrick on colloids in distilled water, and Prof. H. S. Taylor on adsorption from silver salt solutions by silver iodide. Visits to electrochemical works are being arranged.

\section{Section C (Geology).}

Ontario, one of the most important mineral-producing areas in the world, must of necessity be intensely interested in geological problems, and no gathering of men of science there could possibly avoid devoting considerable attention to that branch of science. While general topics are of interest in any or all circumstances, the industrial applications of geological knowledge are of paramount importance here. In addition, it is not without advantage that the problems confronting geologists and mining men in Canada are largely connected with the most ancient rocks of which we have any knowledge. Consequently the programme of Section $\mathrm{C}$ has been designed to stimulate, so far as possible, interest in both pure and applied geological science. The president, Prof. W. W. Watts, has selected as the subject of his address "Geology in the Service of Man," while subsequent speakers will emphasise particular aspects of applied geology as evidenced in Canada, and more especially in Northern Ontario. Inextricably bound up with the practical side of geology in Canada are the various problems connected with Pre-Cambrian rocks (indeed the word Pre-Cambrian is almost a household word in Ontario), and a whole session will be devoted to consideration of problems associated with these rocks in many parts of the world.

Appealing more strongly perhaps to another group of the public will be the joint discussion with the geographical section on changes of sea-level in relation to glaciation, coast-lines, etc., while a third on liquid and powdered fuels has been arranged as a joint discussion with Section B (Chemistry). This latter has had to be fixed to run concurrently with another meeting as the time available will not suffice for all the activities of the Section. NO. 2856 , VOL. I I 4 ] 
While such questions of general interest will occupy a considerable part of the sessions, the results of recent research work on more special subjects will be expounded by many authors. Mineralogy, petrology, palæontology, and stratigraphical geology will all be represented, so that every branch of geological interest will have its exponents.

As is usual in the case of Section C, excursions to places of interest round Toronto will form an important part of the programme. Three such excursions have already been settled, one being a weekend trip to the Niagara and Grimsby districts. Others will probably be fixed during the meeting, and members are advised to consult the notice boards outside the sectional rooms from time to time. On the western trip following the meeting, opportunities will be given for geologists to examine selected areas en route, but such areas must of necessity be determined by factors not entirely geological.

\section{Section E (Geography).}

The address by the sectional president, Prof. J. W. Gregory, will deal with "Inter-Racial Problems and White Colonisation in the Tropics." Another paper on allied problems will be on "Immigration from a Biological Point of View " by Dr. H. H. Laughlin. Many of the papers will treat of various aspects of Canadian geography, including Dr. Bell Dawson on "Tides and Currents in Canadian Waters," and Mr. E. M. Dennis, Mr. W. H. Boyd, Mr. N. Ogilvie, and Mr. W. H. Herbert on different branches of the work of the topographical survey of Canada. Dr. R. M. Anderson will speak on the status and prospects of the larger mammals of Canada.

Papers dealing with cartography and allied problems will be given by Mr. I. Bartholomew on modern developments in the construction of maps and $\mathrm{Mr}$. J. B. Reynolds on the work of the Permanent Committee on Place-Names. Important papers in physical geography include "Wind, Wave, and Swell in the North Atlantic" by Dr. Vaughan Cornish, "Classification of Oceanic Islands" by Prof. W. M. Davis, and "The Glacial Anticyclone" by Prof. W. H. Hobbs. Prof. P. M. Roxby will lecture on the distribution of population in China, and Mr. Cuthbert Christy on Cape to Cairo progress.

Papers in human geography also include one on some aspects of urban growth by Mr. H. L. Seymour, and another on the influence of geographic conditions on the ancient. Mediterranean religions by Miss E. C. Semple. Miss M. I. Newbigin's paper on the training of the geographer should direct attention to the notable lack of such facilities in Canada.

\section{Section F (Economic Science and Statistics).}

The programme for the Economics Section at the Toronto meeting covers a wide and important field. Sir William Ashley's presidential address is " A Retrospect of Free Trade Doctrine." Business forecasting will be discussed by Prof. W. N. Persons, Mr. R. H. Coates, Prof. Mitchell, and Prof. H. W. Mackintosh.

The problem of population is to be dealt with in four papers from different points of view ; Sir William Beveridge dealing with the fall of human fertility among the European races, and some of its reactions, Mr. Udny Yule with the population problem from the point of view of the Pearl and Reed law of growth, Prof. MacIver with civilisation and population, and Prof. Field with eugenic worth and economic value. Prof. J. E. Boyle is contributing a paper on the marketing of grain, and a film is to be shown illustrating - the marketing of wheat. A discussion is to be held jointly with the Agriculture Section on diminish- ing returns in agriculture, and papers are to be read by Prof. C. R. Fay and Sir John Russell. Prof. A. L. Bowley will read a paper on the economic outlook in Great Britain, and the problem of unemployment prevention and insurance is to be discussed in papers by Prof. J. R. Commons and Mr. Bryce M. Stewart.

The meetings of the section will, therefore, bring together many of the leading economists of Great Britain, Canada, and the United States.

\section{Section G (EngINEERING)}

The programme of the Section opens with Prof. G. W. O. Howe's presidential address entitled "One Hundred Years of Electrical Engineering." The remaining papers to be presented fall practically into two big groups: Canadian engineering problems and the strength of materials.

The first group is to be opened by Sir Henry Thornton, president of the Canadian National Railways, who will discuss railway transportation in Canada. This will be followed by a paper from Lieut.-Col. H. S. Lamb on engineering problems and traffic on the Great Lakes. Mr. J. B. Challies, director of the Water-Power and Reclamation Service, is to deal with the water-power resources of Canada. Water-power development commenced in I 895, and its possibilities may be envisaged from the fact that during the past ten years, while the population has increased 22 per cent., the water-power in use has increased nearly too per cent., and its use in industry 245 per cent. The total water-power of the Dominion is estimated at I 8,000,000 horse-power, of which nearly $3,250,000$ horse-power has been developed and 750,000 is under construction. The story will be taken up by Mr. F. A. Gaby, chief engineer of the Ontario Hydro-Electric, who will deal with the Hydro-Electric Power Commission of Ontario, and by Mr. R. S. Lea, who will discuss the possibilities of power development of the St. Lawrence River. A visit to the Niagara Fall Power Houses will be an appropriate conclusion to this part of the Section's work.

The second part of the programme will be opened by Prof. E. G. Coker with Mr. A. L. Kimball, of the General Electrical Company, Schenectady, who will describe American experiments on the optical determination of stress. Profs. H. F. Moore and T. M. Jasper, of Illinois University, will discuss the evidence for the existence of an endurance limit in metals, Prof. F. C. Lea, the effect of high temperature on the range of repetition stress for steels, and there are several other papers on related topics. The whole subject may be expected to be dealt with in two reports to be presented to the Section, one by Prof. C. F. Jenkin, on the work of the Fatigue Panel of the Aeronautical Research Committee, and another on the work of the Complex Stress Committee.

Other subjects to be dealt with by the Section include questions of public health (Mr. F. A. Dallyn), bio-aeration in sewage disposal (Mr. J. D. Watson), cobalt magnetic steels (Mr. E. A. Watson), and the future of power from fuel (Mr. E. K. Scott).

\section{Section H (ANTHRopology).}

Communications by anthropologists from Canada and the United States provide the greater part of the programme of the Section. Dr. F. C. Shrubsall's presidential address is entitled " Health and Physique through the Centuries." Other British contributions will include papers by Dr. A. C. Haddon on " A Suggested Arrangement of the Races of Man "; Dr. T. Ashby on "Recent Archæological Discoveries in Italy" ; Mr. H. Balfour on "The Welfare of Primitive 
Peoples," and also on "The Art of Stencilling in the Fiji Islands"; Mr. L. H. Dudley Buxton on "Skulls from the Valley of Mexico," and on "Physical Observations on Navajo Children." Prof. H. J. Rose's paper, "The Bride of Hades," will deal with virgin sacrifice as a fertility rite in early Greece and Rome.

Of communications by Canadian anthropologists, a number will deal with work which has been done under the Anthropological Department of the Geological Survey. Mr. Jenness deals with "The Ancient Education of a Carrier Indian " ; Mr. T. F. McIlwraith with "The Potlach in Bella Coola," the result of a personal and, possibly, a unique experience; Miss E. G. Spier will analyse the "Ceremony of the First Salmon," and Mr.G.E. Rhoades will discuss "Composition in the Art of the North-west Coast Indians." From the United States Dr. A. Hrdlička will discuss the antiquity of man in America in the light of recent discoveries, with special reference to the skeletal remains recently found at Los Angeles. Mr. B. Oetteking also will give an account of the Santa Barbara skeletal remains; and Mr. Harlan I. Smith will describe "Trephined Aboriginal Skulls from Columbia and Washington." Dr. C. Wissler will deal with "The Segregation of Racial Characters in a Population," and Dr. Laughlin, of the Statistical Bureau, New York, will give an account of some racial characters emerging from the data obtained from immigrants. A joint discussion with Section (Psychology) on "Racial Mental Differences" will be opened by Prof. W. McDougall.

\section{Section I (Physiology).}

The provisional programme arranged for the Section is the largest there has been for many years. It contains more than forty communications, covering a very wide range of subjects in physiology, biochemistry, and practical applications of these subjects to medicine.

The proceedings of the Section will open with the address of its president, Dr. H. H. Dale, on " Progress and Prospects in Chemotherapy." There are two joint discussions on the programme, one with Section $B$ (Chemistry) and one with Section J (Psychology). The joint discussion with Section $J$ will be on "Physiological and Psychological Factors of Muscular Efficiency in Industry," and will comprise the following papers among others: Prof. C. Lovatt Evans, "The Physiology of Muscular Contraction in Relation to Efficiency and Fatigue" ; Prof. E. A. Bott, "Co-ordinate Volitional Action of Antagonistic Muscular Groups "; Prof, E. P. Cathcart, " Energy Exchange in Relation to Muscular Performance in Laboratory Investigations"; Prof. C. S. Myers, "Conceptions of Fatigue," and Prof. F. S. Lee, "Physical and Chemical Tests for Fatigue."

The joint discussion with the Chemistry Section will be entitled "Vitamins, and the Relation of Light to their Action," and the following are included in the papers to be contributed to it: Prof. J. C. Drummond, "Modern Tendencies of Vitamin Research"; Prof. H. C. Sherman, "The Quantitative Distribution and Nutritional Significance of Fat-soluble Vitamin", Prof. Walter H. Eddy, " The Isolation of a Bios from Autolysed Yeast"; Prof. E. Mellanby (title not given); Prof. W. Lash Miller, "Bios"; and Prof. W. Steenbock, " Radiant Energy as the Anti-rachitic Factor."

Meeting at Toronto, it is appropriate that the Section should hear something of insulin, and Prof. J. J. R. Macleod and Mr. C. H. Best are, among others, dealing with this interesting subject.

Prof. J. C. Drummond is to deliver a popular lecture on "Cod-liver Oil."

$$
\text { NO. } 2856 \text {, VOL. I I } 4]
$$

There will be a large number of United States visitors at the Physiology Section.

\section{Section J (Psychology).}

The papers this year are so diverse in character that it is difficult to group them all under a few general headings. The presidential address by Prof. W. McDougall is entitled "Purposive Striving as a Fundamental Category in Psychology."

Three joint discussions have been arranged: (a) With Section H (Anthropology), on "Racial Mental Differences." Speakers-Prof. W. McDougall, Dr. C. S. Myers, and others. (b) With Section I (Physiology), on "Physiological and Psychological Factors of Muscular Efficiency in Industry." SpeakersProf. Lovatt Evans, Prof. E. A. Bott, Prof. E. P. Cathcart, Dr. C. S. Myers, Prof. F. S. Lee. (c) With Section L (Education), on " Tests for Scholarships and Promotion." Speakers-Principal E. Barker, Prof. C. Burt, Prof. Sandiford, Prof. Whipple, and Prof. Buckingham.

A welcome feature of the programme is the important contributions of American and Canadian psychologists ; for example, "The Problem of Personality," by Dr. Morton Prince, and "The Value of Mnemic Psychology for the Interpretation of Dreams and other Phenomena," by Prof. G. S. Brett, the local vice-president of the Section. A new feature is an informal conference of experimentalists on laboratory and applied researches, to be held on Saturday morning, August 9, Dr. C. S. Myers presiding, when several American, Canadian, and British representatives will exchange views.

Individual papers by British psychologists are: " The 'Self' in Cognition--Intuition, Concept, and Sensory Percept," by the Rev. F. Aveling; "Binocular Vision and Correct Ocular Muscle Balance: its Importance in Every-day Life," by Wing-Commander E. C. Clements ; (I) "Psychological Theories of Laughter," (2) "Conscious and Unconscious in Psychology," by Dr. J. Drever ; "Feeling and Emotion in Daily Life," by Mr. J. C. Flügel ; " The Psychology of Déjà Vu," by Dr. J. T. MacCurdy "Privileges and Limitations of Visual Imagery," by Prof. T. H. Pear ; and "Shape-qualities or Relations?" by Prof. C. Spearman.

\section{Section K (Botany).}

The programme of the Section is noteworthy for the time which is to be devoted to discussions, either within the Section itself or in conjunction with other Sections. The proceedings start with a discussion on the ascent of sap and transport of food materials in trees, which will be opened by Prof. H. H. Dixon: other speakers will include Dr. O. F. Curtis, of Cornell University, Dr. D. F. MacDougal, Prof. V. H. Blackman, and Prof. J. H. Priestley. Another sectional discussion is to be on Canadian forest problems: the speakers at this meeting include Mr. D. Roy Cameron and Dr. J. M. Swaine, who will deal with forest protection in Canada from fire and insects respectively; Mr. E. H. Finlayson on Canadian silviculture, Dr, A. W. Borthwick on the cultivation outside Canada of Canadian trees, and Messrs. R. D. Craig and F. Storey on world timber supplies.

Joint discussions have been arranged with the Sections of Agriculture and Zoology respectively. At the former, the subject will be "Forest Problems," and four papers on aspects of forestry in the United States and in Canada will be contributed by Mr. J. W. Toumey, Mr. R. D. Craig, Prof. J. H. Faull, of the University of Toronto, and Mr. E. J. Zavitz. This discussion, by representatives from two of the greatest timber-producing countries of the world, should prove of great interest and importance. The 
joint meeting with Section D (Zoology) will be to discuss the subject of "Species and Chromosomes." It will be opened by Prof. R. Ruggles Gates, and other speakers are Dr. H. Harrison, Prof. T. H. Morgan, of Columbia University, Mr. Julian Huxley, Miss K. Blackburn, and Mr. A. D. Peacock.

Prof. V. H. Blackman's presidential address to the Section will be entitled "Physiological Aspects of Parasitism." Of the numerous papers to be presented, it is impossible to mention more than a few. Contributions from the North American continent include papers on the "black dot" disease of potato, by Prof. B. T. Dickson; on the fluorescent pigments of the Cyanophyceæ, by Prof. F. E. Lloyd; on the distribution of potassium in plant tissues, by Miss E. S. Dowding; on the status of the biogenic law, by Prof. E. C. Jeffrey; on the growth of British Columbia trees, by Prof. A. H. Hutchinson; and on the behaviour of chloroplasts and other cell contents at low temperature, by Prof. F. J. Lewis. A number of papers will also be presented by British botanists.

\section{Section L (Educational Science).}

The Section is to open its session with a paper on the teaching of history and geography of the British Empire by Prof. G. M. Wrong, of the University of Toronto, followed by a paper on modern tendencies in the teaching of geography, by Mr. Ernest Young. The presentation of the Report of the special committee appointed last year to inquire into the educational training of boys and girls in secondary schools for life overseas will be followed by a discussion on the subject to be opened by Sir John Russell.

On the second day Principal Ernest Barker will deliver his presidential address, the subject being the "Nature and Conditions of Academic Freedom in Universities." Mr. A. E. Heath, of the University of Liverpool, will follow with a paper on "Modern Developments in the Method and Scope of Adult Education." A joint discussion with Section J (Psychology) on the subject of "Tests for Scholarships and Promotions " will occupy the third morning; the chief speakers will be Principal Barker, Prof. Cyril Burt, Prof. G. M. Whipple, Prof. B. R. Buckingham, and Prof. Sandiford. The latter in conjunction with Messrs. Brennan and Holmes will also contribute a paper on "The Use of Partial Coefficients of Correlation in Educational Research."

A discussion on "Modern Developments in Science Teaching " is to be opened by Mr. C. M. Stuart, late headmaster of St. Dunstan's School, Catford. Prof. J. L. Myres will read a paper on the place of classics in a secondary school system, to be followed by Mr. A. H. Hope, headmaster of Roan School, Greenwich, on the present position of classics in French secondary schools. The fourth morning will be devoted specially to subjects of Canadian interests. Sir Robert Falconer, president of the University of Toronto, will read a paper on "The Canadian University" ; the Hon. Dr. H. J. Cody on the administration of educa- tion in Canada ; Prof. G. M. Weir on an educational experiment in rural Saskatchewan; Dr. S. B. Sinclair on the selection of pupils for auxiliary classes; and Major J. B. Cowles on the working of the Adolescent Education Act in Ontario.

\section{Section M (Agriculture).}

The meetings of Section $M$ will be held under the presidency of Sir John Russell, the director of the Rothamsted Experiment Station, whose address on "Combination in tackling Farmers' Problems" will be given on Monday, August Io.

The proceedings on Thursday, August 7, will be opened by a short address by the Hon. J. S. Martin, Minister of Agriculture for the Province of Ontario. $\mathrm{He}$ will be followed by Dr. F. T. Shutt on "The Influence of Cropping on the Nitrogen and Organic Matter Content of Western Prairie Soils." Mr. H. J. Page, the head of the Chemical Department at Rothamsted, will read a paper on " Nitrogen Balance in the Soil "; and he will be followed by Dr. Scott Robertson on "The Fertilising Effect of Rock Phosphate." The next morning will be occupied by a joint discussion with Section D (Zoology) on "The Soil Population." This will be opened by Mr. D. Ward Cutler. In the afternoon, Mr. J. B. Reynolds, the principal of the Guelph Agricultural College, will speak on "Agricultural Colleges in Canada.',

On Saturday, August 9, Mr. R. A. Fisher, of Rothamsted, will read a paper on "The Incidence of Rainfall in Relation to the Wheat Crop," and later in the morning Dr. McRostie will speak on "Forage Crops in Canada." The same day, Mr. Engledow will read a paper on "A Spacing Experiment with Wheat," which will terminate the day's proceedings.

On Monday, August II, Mr. Godden will speak on the work which is being carried out at the Rowett Research Institute on the mineral requirements of farm animals, and Prof. Berry will follow with a paper on "The Chemistry of the Oat Crop." The afternoon will be occupied by a joint meeting with Section K (Botany) on "Forest Problems in Canada," to which Mr. Zavitz and Dr. Faull are contributing.

On Tuesday, August 12, the whole morning will be devoted to a joint meeting with Section $F$ (Economics), the subject for discussion being "Diminishing Returns in Agriculture." This discussion will be opened by Dr. C. R. Fay, and it is hoped that other speakers will include Sir John Russell, Lord Bledisloe, Sir Henry Rew, and Mr. Ashby.

The proceedings of the Section will conclude with a joint meeting on forestry with Section $K$, in which such subjects as forest protection in Canada, and the cultivation of Canadian trees in other parts of the world, will be brought forward.

After the conclusion of the meeting, several local excursions have been arranged, including a visit to the Agricultural College at Guelph.

\section{Atoms and Ethereal Radiations. ${ }^{1}$}

$\mathrm{N}$ his first lecture the speaker, after outlining the steps by which he and his collaborators had succeeded in pushing the region of wave-lengths explored by mechanically ruled gratings down to I 36 Angströms, presented the results which had very recently been

1 Abstract, prepared by the author, of three lectures delivered on June $\mathrm{I} 6,17$, and $\mathrm{r} 8$, at University College, London, by Robert A. Millikan, Director of the Norman Bridge Laboratory of Physics of the California Institute, Pasadena, entitled ( $\mathrm{I}$ ) "Filling in the Gap between X-rays and Light", (2) "Electronic Orbits in Atoms"; (3) "The Penetrating Radiations of the Upper Air."

No. 2856 , voL. I I 4$]$ obtained by Mr. I. S. Bowen and himself, through the analysis, with the use of high resolution, of the fine structure of these extreme ultra-violet lines.

Photographs were shown in which such a close doublet as the $\mathrm{B}_{11}$ line at 677 Angströms was not only clearly resolved, but had its components so well separated that their distance apart, which amounted to but 0.15 Angströms, could be measured with certainty to $\mathrm{O} \cdot \mathrm{OI}$ Ingströms or better, and in which the seven components of the $834^{\circ}$ o line of oxygen were 